\title{
CHANGE PECULIARITIES OF THE FUNCTIONAL STATE OF THE CARDIORESPIRATORY SYSTEM OF FOOTBALL PLAYERS AT THE AGE OF 15-17 UNDER THE INFLUENCE OF THE EXPERIMENTAL PROGRAM OF ANNUAL MICROCYCLE TRAINING SESSION
}

\author{
Vladimir Silin \\ Postgraduate Student, Zaporizhzhia National University, Ukraine \\ e-mail: silinho1988@gmail.com,orcid.org/0000-0002-4452-5429 \\ Mykola Malikov \\ Doctor of Biological Sciences, Professor, \\ Dean of the Faculty of Physical Education, Health and Tourism, \\ Zaporizhzhia National University, Ukraine \\ e-mail: nvmalikov1957@gmail.com,orcid.org/0000-0001-8033-872x
}

\author{
Andrii Svatiev \\ Doctor of Pedagogical Sciences, Professor, \\ Head of the Department of Physical Culture and Sports, \\ Zaporizhzhia National University, Ukraine \\ e-mail: 29011973@ukr.net, orcid.org/0000-0001-9399-1576
}

\section{Summary}

The optimal form of organization of the training process, taking into account current trends in football, can ensure the achievement of the appropriate level of training of players and high sports results. Objective: to evaluate the effectiveness of the experimental program of the training process of football players aged 15-17 in the preparatory period of the annual macrocycle to improve their functional prepqredness in preparation for the competitive season. Material and methods of the study: the study involved 29 football players aged 15-17 years, who are engaged in this type of sports games at the stage of specialized basic training. Results: it is shown that the use of the traditional program for the preparatory period of the annual training cycle in the training process did not significantly improve the level of their overall functional preparedness, namely: by the end of the training season they showed a significant improvement only in heart rate (by 9\%), hypoxia index (by 13\%) and the cardio-vascular system functional state level $(9 \%)$. Changes in other indicators were not statistically significant and ranged from only $2 \%$ to $10 \%$. On the contrary, the introduction in the preparatory period of the annual macrocycle of the proposed program to build the training process of football players aged 15-17 contributed to significant positive changes in their overall functional preparedness: by the end of the study the experimental group had significant positive changes by $8-70 \%$ compared to the original data. It should be noted that at the end of the preparatory period for the players of the experimental group were characterized by significantly higher than in the control group, the rate of reduction of functional stress (by 15-20\%), increased adaptive capacity (by 50\%), their body's resistance to hypoxia (by 15\%), as well as increasing the cardio-vascular system functional state level by $5 \%$, and the external breathing system functional state level by $18 \%$. Conclusions: the obtained results testified to the high efficiency of the experimental program of building the training process of football players aged 15-17 in the preparatory period of the annual macrocycle.

Keywords: functional state, cardiorespiratory system, preparatory period, football players aged 15-17, training process, experimental program.

DOI: https://doi.org/10.23856/4515 


\section{Introduction}

The problem of optimizing the functional preparedness of football players on the different stages of long-term sports training still remains one of the most relevant in the field of sports excellence (Bujalance-Moreno, Latorre-Román, García-Pinillos, 2019: 927; Turna, Alp, 2020: 168).

This is due to the significant role of the functional preparedness of athletes in ensuring the optimal implementation of other types of general training, including physical and technical-tactical preparedness, directly in the process of competitive activity.

According to most experts, the optimal level of functional preparedness of athletes, in turn, requires an appropriate level of functional state of the leading physiological systems of the body, especially the cardiovascular system and the respiratory system (Dyachenko A., 2000: 48; Mizchenko V., Tomyak T., Dyachenko A. 2003: 60; Malikov et al, 2020: 2688; 2021: 379).

In connection with the above study of the functional state of football players on the different stages of sports training, in particular at the initial stages, is devoted to a large number of scientific studies (Lisenchuk, Tishchenko, 2019: 179; Strykalenko, Shalar, Husar, Boychenko, 2020: 94; Barba, Iturriaga, Borges-Fernandes, 2020: 1785; Menegassi et al, 2018: 171).

However, it should be noted that the current level of development of high-achievement sports, including football, the growing demands on the general condition of players, their physical and functional preparedness, requires the search for new innovative approaches to building the training process, especially in preparation for the competitive season.

Obviously, only the optimal form of organization of the training process, taking into account current trends in football, can ensure the achievement of the appropriate level of training of players and high sports results. According to most experts, an important criterion for evaluating the effectiveness of new experimental programs to build a training process can be the functional state of the cardiorespiratory system of their body.

The relevance and undoubted practical significance of this problem became the prerequisites for this study.

Connection of research with scientific programs, plans, topics. The work was performed within the state budget theme "Modern technologies for training athletes of different specializations and qualifications in Olympic sports" (state registration number-0116U004848) Thematic plan of research work of Zaporozhzhian National University for 2016-2020.

The purpose of the study: to evaluate the effectiveness of the experimental program of the training process of football players aged 15-17 in the preparatory period of the annual macrocycle to improve their functional preparedness in preparation for the competitive season.

Material and research methods. The study involved 29 football players aged 15-17, who are engaged in this sport at the stage of specialized basic training. All players were divided into control (14 athletes) and experimental (15 athletes) groups.

The football players of the control group were engaged in the traditional program in football (Nikolaenko, Avramenko, Goncharenko, 2003), and the athletes of the experimental group according to the experimental training program developed by us.

Organization of the study. The evaluation of the effectiveness of the experimental program of the training process was carried out on the basis of a comparative analysis of changes in the circulatory and external respiration of football players of the control and experimental groups within the preparatory period of the annual macrocycle. 
The main features of the experimental program were the redistribution of training loads of different orientations, namely: within the general-preparatory and special-preparatory stages it was proposed to increase the amount of training loads by 6 hours to increase the level of special physical preparedness by reducing the corresponding amount by 2 hours to general physical, technical and tactical training; in the first half before the competitive stage it was proposed to increase the amount of training sessions on special physical training by 4 hours by reducing the amount of general physical and tactical training by 2 hours, and in the second half of this stage it was planned to increase the amount of special physical training by 4 hours reduction by 2 hours of technical and tactical training.

In addition, as part of the general preparatory stage, it was proposed in the 1st, 2nd and 3rd microcycles to increase by $5 \%$ the amount of training loads for the development of speed and strength and speed endurance by reducing in each of these microcycles by $10 \%$ of the amount of funds aimed at developing overall endurance.

In all of four microcycles of the special-preparatory stage it was proposed to increase by $5 \%$ the amount of training loads of speed-power orientation due to the corresponding reduction of training loads aimed at the development of general endurance.

As part of the pre-competition stage, it was proposed to increase by $5 \%$ the amount of training loads aimed at the development of speed and strength abilities in the 1st, 2nd, 3rd, 7th and 8 th microcycles and to reduce by $5 \%$ in 4 - th and 5th microcycles. The load on the development of speed abilities was proposed to be reduced by $5 \%$ in the $3 \mathrm{rd}$, 7 th and 8 th microcycles, but to increase in the 4 th and 5 th microcycles. It was proposed to reduce the amount of training loads aimed at increasing the overall endurance of athletes in the 1 st and 2 nd microcycles.

Testing was performed at the beginning (December) and at the end (March) of the preparatory period of the annual macrocycle.

Methods of variational and amplitude pulsometry, spirometry and the computer program "SHVSM-integral" were used to assess the functional state of the cardiovascular system and the external respiratory system (Malikov, Bogdanovskaya, Svatyev, 2006). The algorithm of inspection within the limits of this program provided definition by means of standard methods of such indicators as heart rate (HR, beats $\left.\cdot \mathrm{min}^{-1}\right)$, systolic (APs, mm of mercury), diastolic (APd, $\mathrm{mm}$ of mercury) blood pressure, vital lung capacity (VLC, ml), inhalation breathing delay tim (Tin, sec), exhalation breathing delay time (Tex, sec) and after entering the data into the program automatic calculation of systolic $(\mathrm{SBV}, \mathrm{ml})$ and minute $\left(\mathrm{HBV}, 1 \cdot \mathrm{min}^{-1}\right)$ blood volumes, heart index $\left(\mathrm{HI}, 1 \cdot \mathrm{min}^{-1} \cdot \mathrm{m}^{-2}\right)$, general peripheral resistance $\left(\mathrm{GPR}, \operatorname{din} \cdot \mathrm{s} \cdot \mathrm{cm}^{-5}\right)$, hypoxia index $(\mathrm{HI}$, conventional units) and Skibinski (SI, conditional units) and the level of functional state of the cardiovascular system (LFScvs, points) and the external breathing system (LFSebs, points).

Statistical processing of the study results was performed using standard software packages "STATISTIKA 7.0" and EXEL with the calculation of the following indicators: arithmetic mean $(\mathrm{X})$, standard deviation $(\delta)$ and the arithmetic mean error $(\mathrm{S})$.

\section{Research results and their discussion}

The results of the initial testing of the functional state of the cardiorespiratory system of football players of both groups allowed to state the following.

At the beginning of the experiment (beginning of the preparatory period) for the players of the control and experimental groups were characterized by almost identical indicators of the cardiovascular and respiratory systems of their body (Table 1). 
Table 1

\section{Indicators of the functional state of the cardiorespiratory system of football players of the control and experimental groups at the beginning of the study, $x \pm S$}

\begin{tabular}{|c|c|c|}
\hline Indicators & $\begin{array}{c}\text { Control } \\
\text { group }(n=14)\end{array}$ & $\begin{array}{l}\text { Experimental } \\
\text { group }(n=15)\end{array}$ \\
\hline Cardiovascular stress index, cond. units & $231,11 \pm 12,67$ & $225,98 \pm 11,95$ \\
\hline Vegetative balance index, cond. units & $236,65 \pm 8,79$ & $231,27 \pm 7,96$ \\
\hline Heart rate indicator, cond. units & $73,42 \pm 2,50$ & $75,20 \pm 1,76$ \\
\hline Adaptive potential of the cardiovascular system, cond. units & $0,33 \pm 0,03$ & $0,35 \pm 0,03$ \\
\hline Systole blood volume, $\mathrm{ml}$ & $64,70 \pm 1,23$ & $66,19 \pm 0,65$ \\
\hline Minute blood volume, L/min & $3,88 \pm 0,07$ & $3,97 \pm 0,04$ \\
\hline Cardiac index, $\mathrm{L} / \mathrm{min} / \mathrm{m}^{2}$ & $2,89 \pm 0,07$ & $2,99 \pm 0,11$ \\
\hline General peripheral resistance, $\operatorname{din}^{2} \times \mathrm{sec} / \mathrm{sm}^{5}$ & $1368,8 \pm 37,01$ & $1306,93 \pm 35,34$ \\
\hline Cardio-vascular system functional state level, points & $70,74 \pm 2,19$ & $73,16 \pm 2,26$ \\
\hline Vital lung capacity, ml & $2520 \pm 78,24$ & $2640 \pm 54,16$ \\
\hline Inhalation breathing delay time, sec. & $73,9 \pm 2,04$ & $75,7 \pm 1,94$ \\
\hline Exhalation breathing delay time, sec. & $32,7 \pm 1,16$ & $35,2 \pm 1,97$ \\
\hline Hypoxia index, cond. units & $0,48 \pm 0,02$ & $0,54 \pm 0,04$ \\
\hline Skibinsky index, cond. units & $2768,47 \pm 137,65$ & $3049,85 \pm 125,38$ \\
\hline External breathing system functional state level, points & $69,21 \pm 0,80$ & $71,41 \pm 1,16$ \\
\hline
\end{tabular}

Among athletes of both groups there were close to each other values of systolic blood volume (SBV) $(64,70 \pm 1,23 \mathrm{ml}$ in the control group and $66,19 \pm 0,65 \mathrm{ml}$ in the experimental group), minute blood volume (MBV) $(3,88 \pm 0,07 \mathrm{~L} / \mathrm{min}$ and 3,97 $\pm 0,04 \mathrm{~L} / \mathrm{min})$, cardiac index (CI) $\left(2,89 \pm 0,07 \mathrm{~L} / \mathrm{min} / \mathrm{m}^{2}\right.$ and $\left.2,99 \pm 0,11 \mathrm{~L} / \mathrm{min} / \mathrm{m}^{2}\right)$ and general peripheral resistance (GPR) $\left(1368,8 \pm 37,01 \mathrm{din}^{2} \times \mathrm{sec} / \mathrm{sm}^{5}\right.$ and $\left.1306,93 \pm 35,34 \mathrm{din}^{2} \times \mathrm{sec} / \mathrm{sm}^{5}\right)$.

It should be noted that at this stage of the study, all players had a fairly high level of functional stress mechanisms of heart rate regulation (the values of cardiovascular stress index (CVSI) were respectively $231,11 \pm 12,67$ c.u. and $225,98 \pm 11,95$ c.u., and the vegetative balance index (VBI) - 236,65 $\pm 8,79$ c.u. and $231,27 \pm 7,96$ c.u.), below the average value of the heart rate indicator (HRI) (respectively $73,42 \pm 2,50$ c.u. and 75,20 $\pm 1,76$ c.u.) and low - adaptive potential of the cardiovascular system (APcvs) $(0,33 \pm 0,03$ c.u. and $0,35 \pm 0,03$ c.u.). However, for players of both groups was characterized by a higher than average level of functional state of the cardiovascular system (LFScvs) (respectively 70,74 $\pm 2,19$ points and 73,16 $\pm 2,26$ points).

The presented data showed that a fairly high level of functional state of the cardiovascular system is provided by a high degree of realization of the functional reserve of the body of football players, which can not be considered as an adequate form of adaptation to regular exercise.

To some extent, this conclusion was confirmed by the results of a comparative analysis of the indicators of the external breathing system of football players aged 15-17 of the control and experimental groups.

At the beginning of the experiment for athletes of both groups was characterized by a higher than average level of functional state of the external breathing system (LFSebs) $69,21 \pm 0,80$ points in the control group and $71,41 \pm 1,16$ points.

However, almost identical, reduced values of such integrated indicators as vital lung capacity (VLC), inhalation breathing delay time (Tin), hypoxia (HI) and Skibinski's (SI) 
indexes indicated that the increased level of functional state of the external breathing system (LFSebs) of football players of both groups is provided by significant mobilization of their body's functional reserve.

In general, the results obtained at the beginning of the experiment showed the relative homogeneity of the players of the control and experimental groups, which is important for further objective interpretation of the study materials.

The next testing of football players of both groups was conducted by us at the end of the preparatory period of the annual macrocycle.

Analysis of changes in the indicators of the cardiorespiratory system in the players of the control group allowed to establish the following (Table 2).

Table 2

Indicators of the functional state of the cardiorespiratory system of control group players at the beginning and end of the study, $\bar{x} \pm S$

\begin{tabular}{|l|c|c|}
\hline \multicolumn{1}{|c|}{ Indicators } & $\begin{array}{c}\text { The beginning of } \\
\text { the experiment }\end{array}$ & $\begin{array}{c}\text { The end of the } \\
\text { experiment }\end{array}$ \\
\hline Cardiovascular stress index, cond. units & $231,11 \pm 12,67$ & $208,41 \pm 11,43$ \\
\hline Vegetative balance index, cond. units & $236,65 \pm 8,79$ & $218,31 \pm 8,11$ \\
\hline Heart rate indicator, cond. units & $73,42 \pm 2,50$ & $79,93 \pm 2,73^{*}$ \\
\hline Adaptive potential of the cardiovascular system, cond. units & $0,33 \pm 0,03$ & $0,40 \pm 0,04$ \\
\hline Systole blood volume, ml & $64,70 \pm 1,23$ & $67,53 \pm 1,28$ \\
\hline Minute blood volume, L/min & $3,87 \pm 0,05$ & $3,88 \pm 0,07$ \\
\hline Cardiac index, L/min/m ${ }^{2}$ & $2,89 \pm 0,07$ & $2,80 \pm 0,07$ \\
\hline General peripheral resistance, dinn ${ }^{2} \times$ sec/sm ${ }^{5}$ & $1368,8 \pm 37,01$ & $1264,91 \pm 34,2$ \\
\hline Cardio-vascular system functional state level, points & $70,74 \pm 2,19$ & $76,93 \pm 2,38^{*}$ \\
\hline Vital lung capacity, ml & $2520 \pm 78,24$ & $2575 \pm 71,98$ \\
\hline Inhalation breathing delay time, sec. & $73,9 \pm 2,04$ & $77,6 \pm 1,86$ \\
\hline Exhalation breathing delay time, sec. & $32,7 \pm 1,16$ & $35,9 \pm 1,36$ \\
\hline Hypoxia index, cond. units & $0,48 \pm 0,02$ & $0,55 \pm 0,03^{*}$ \\
\hline Skibinsky index, cond. units & $2768,47 \pm 137,65$ & $3064,22 \pm 144,83$ \\
\hline External breathing system functional state level, points & $69,21 \pm 0,80$ & $71,23 \pm 0,84$ \\
\hline
\end{tabular}

Note: ${ }^{*}-\mathrm{p}<0.05$ compared to the beginning of the experiment.

Prior to the end of the experiment, they were characterized by a positive tendency to reduce the degree of functional stress of the regulatory mechanisms of the cardiovascular system, as evidenced by a decrease in CVSI and VBI, as well as a tendency to increase integrated indicators such as systolic and minute blood volumes, adaptive potential, vital lung capacity, inhalation and exhalation breathing delay time, Skibinsky index. At the same time, only positive changes in heart rate indicator (HRI) (up to 79,93 $\pm 2,73$ c.u.), hypoxia index (up to $0,5 \pm 0,03$ c.u.) and cardio-vascular system functional state level (up to $76,93 \pm 2,38$ points) were statistically significant. Based on the obtained data, it could be said that the use of the traditional training program in the training process did not fully optimize the functional state of the cardiorespiratory system of the control team until the end of the preparatory period of the annual training cycle.

On the contrary, the football players of 15-17 years of the experimental group to the end of experiment showed a significant improvement in all indicators of the functional state of the cardiorespiratory system of their body (Table 3 ). 
Table 3

Indicators of the functional state of the cardiorespiratory system of the experimental group players at the beginning and end of the study, $x \pm S$

\begin{tabular}{|l|c|c|}
\hline \multicolumn{1}{|c|}{ Indicators } & $\begin{array}{c}\text { The beginning of } \\
\text { the experiment }\end{array}$ & $\begin{array}{c}\text { The end of the } \\
\text { experiment }\end{array}$ \\
\hline Cardiovascular stress index, cond. units & $225,98 \pm 11,95$ & $158,8 \pm 9,56^{* * *}$ \\
\hline Vegetative balance index, cond. units & $231,27 \pm 7,96$ & $178,82 \pm 6,5^{* * *}$ \\
\hline Heart rate indicator, cond. units & $75,2 \pm 1,76$ & $88,43 \pm 4,26^{* *}$ \\
\hline Adaptive potential of the cardiovascular system, cond. units & $0,35 \pm 0,03$ & $0,59 \pm 0,07 * *$ \\
\hline Systole blood volume, ml & $66,19 \pm 0,65$ & $69,42 \pm 1,43^{*}$ \\
\hline Minute blood volume, L/min & $3,97 \pm 0,04$ & $4,17 \pm 0,09^{*}$ \\
\hline Cardiac index, L/min/m ${ }^{2}$ & $2,99 \pm 0,11$ & $2,56 \pm 0,03^{* * *}$ \\
\hline General peripheral resistance, din ${ }^{2} \times$ sec/sm ${ }^{5}$ & $1306,93 \pm 35,34$ & $1196,68 \pm 32,3 *$ \\
\hline Cardio-vascular system functional state level, points & $73,16 \pm 2,26$ & $83,53 \pm 1,8^{* *}$ \\
\hline Vital lung capacity, ml & $2640 \pm 54,16$ & $2845 \pm 46,22^{* *}$ \\
\hline Inhalation breathing delay time, sec. & $75,7 \pm 1,94$ & $82,3 \pm 1,43^{* *}$ \\
\hline Exhalation breathing delay time, sec. & $35,2 \pm 1,97$ & $42,5 \pm 1,44 * *$ \\
\hline Hypoxia index, cond. units & $0,54 \pm 0,04$ & $0,69 \pm 0,03 * *$ \\
\hline Skibinsky index, cond. units & $3049,85 \pm 125,38$ & $3807,76 \pm 110,8^{* * *}$ \\
\hline External breathing system functional state level, points & $71,41 \pm 1,16$ & $86,55 \pm 1,4^{* * *}$ \\
\hline
\end{tabular}

Note: ${ }^{*}-\mathrm{p}<0,05 ; * *-\mathrm{p}<0.01 ; * * *-\mathrm{p}<0,001$ compared to the beginning of the experiment.

By the end of the study, they had a significant decrease in the values of CVSI and VBI (respectively $158,8 \pm 9.56 \mathrm{c}$.u. and $178,82 \pm 6,5$ c.u.), general peripheral resistance (up to $1196,68 \pm 32,3 \mathrm{din}^{2} \times \mathrm{sec} / \mathrm{sm}^{5}$ ) and, conversely, a significant increase in the values of HRI (up to $88,43 \pm 4,26$ c.u.), APcvs (up to $0,59 \pm 0,07$ c.u.), SBV and MBV (respectively 69,42 $\pm 1,43 \mathrm{ml}$ and 4,17 $\pm 0,09 \mathrm{~L} / \mathrm{min}$ ), vital lung capacity (up to $2845,00 \pm 46,22 \mathrm{ml}$ ), inhalation and exhalation breathing delay time (according to 82,3 $\pm 1,43 \mathrm{sec}$ and 42,5 $\pm 1,44 \mathrm{sec}$ ), hypoxia and Skibinski indexes (up to $0,69 \pm 0,03$ c.u. and $3807,76 \pm 110,8$ c.u.), cardio-vascular system functional state level and external breathing system functional state level (respectively $83,53 \pm 1,8$ points and $86,55 \pm 1,4$ points), which were already considered high.

This was confirmed by the results of the comparative analysis presented in table 4 .

After the experiment for the experimental group were characterized by significantly lower, than in the control group, the values of the cardiovascular stress index (respectively $158,8 \pm 9,56$ c.u. and $208,41 \pm 11,43$ c.u. $)$, vegetative balance index $(178,82 \pm 6,5$ c.u. and $218,31 \pm 8,11$ c.u.) and higher values of the adaptive potential of the cardiovascular system

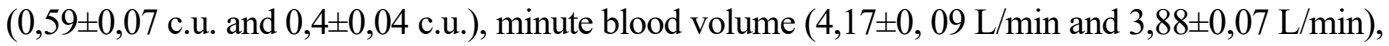
vital lung capacity $(2845,00 \pm 46,22 \mathrm{ml}$ and $2575,00 \pm 71,98 \mathrm{ml})$, the inhalation breathing delay time $(82,3 \pm 1,43 \mathrm{sec}$ and $77,6 \pm 1,86 \mathrm{sec})$ and exhalation breathing delay time $(42,5 \pm 1,44 \mathrm{sec}$ and $35,9 \pm 1,36 \mathrm{sec})$, hypoxia index $(0,69 \pm 0,03$ c.u. and $0,55 \pm 0,03$ c.u. $)$ and Skibinski index $(3807,76 \pm 110,8$ c.u. and $3064,22 \pm 144,83$ c.u. $)$, cardio-vascular system functional state level $(83,53 \pm 1,8$ points and $76,93 \pm 2,38$ points $)$ and external breathing system functional state level $(86,55 \pm 1,4$ points and $71,23 \pm 0,84$ points $)$.

The presented data convincingly testified to the pronounced positive impact of the training program developed by us on the general level of functional preparedness of football players aged 15-17, who train at the stage of specialized basic training. 
Table 4

Indicators of the functional state of the cardiorespiratory system of the control and experimental groups players at the end of the study, $x \pm S$

\begin{tabular}{|l|c|c|}
\hline \multicolumn{1}{|c|}{ Indicators } & $\begin{array}{c}\text { Control group } \\
(\mathbf{n = 1 4 )}\end{array}$ & $\begin{array}{c}\text { Experimental group } \\
\text { (n=15) }\end{array}$ \\
\hline Cardiovascular stress index, cond. units & $208,41 \pm 11,43$ & $158,8 \pm 9,56^{* * *}$ \\
\hline Vegetative balance index, cond. units & $218,31 \pm 8,11$ & $178,82 \pm 6,5^{* * *}$ \\
\hline Heart rate indicator, cond. units & $79,93 \pm 2,73$ & $88,43 \pm 4,26^{* *}$ \\
\hline $\begin{array}{l}\text { Adaptive potential of the cardiovascular system, } \\
\text { cond. units }\end{array}$ & $0,40 \pm 0,04$ & $0,59 \pm 0,07 * *$ \\
\hline Systole blood volume, ml & $67,53 \pm 1,28$ & $69,42 \pm 1,43$ \\
\hline Minute blood volume, L/min & $3,88 \pm 0,07$ & $4,17 \pm 0,09 *$ \\
\hline Cardiac index, L/min/m ${ }^{2}$ & $2,80 \pm 0,07$ & $2,56 \pm 0,03 * *$ \\
\hline General peripheral resistance, din' ${ }^{2} \times$ sec/sm ${ }^{5}$ & $1264,91 \pm 34,2$ & $1196,68 \pm 32,3$ \\
\hline Cardio-vascular system functional state level, points & $76,93 \pm 2,38$ & $83,53 \pm 1,8^{* *}$ \\
\hline Vital lung capacity, ml & $2575 \pm 71,98$ & $2845 \pm 46,22^{* *}$ \\
\hline Inhalation breathing delay time, sec. & $77,6 \pm 1,86$ & $82,3 \pm 1,43^{*}$ \\
\hline Exhalation breathing delay time, sec. & $35,9 \pm 1,36$ & $42,5 \pm 1,44 * *$ \\
\hline Hypoxia index, cond. units & $0,55 \pm 0,03$ & $0,69 \pm 0,03 * *$ \\
\hline Skibinsky index, cond. units & $3064,22 \pm 144,83$ & $3807,76 \pm 110,8^{* * *}$ \\
\hline External breathing system functional state level, points & $71,23 \pm 0,84$ & $86,55 \pm 1,4^{* * *}$ \\
\hline
\end{tabular}

Note: ${ }^{*}-\mathrm{p}<0,05 ; * *-\mathrm{p}<0.01 ; * * *-\mathrm{p}<0,001$ in comparison with the control group.

Table 5

\section{Values of relative changes in the indicators of the cardiorespiratory system of football players aged 15-17 of the control and experimental groups after the experiment (in \% to baseline values)}

\begin{tabular}{|l|c|c|}
\hline \multicolumn{1}{|c|}{ Indicators } & $\begin{array}{c}\text { Control } \\
\text { group (n=14) }\end{array}$ & $\begin{array}{c}\text { Experimental } \\
\text { group (n=15) }\end{array}$ \\
\hline Cardiovascular stress index, cond. units & $-9,82 \pm 1,35$ & $-29,73 \pm 1,28^{* * *}$ \\
\hline Vegetative balance index, cond. units & $-7,75 \pm 1,36$ & $-22,68 \pm 1,29 * * *$ \\
\hline Heart rate indicator, cond. units & $8,87 \pm 1,48$ & $17,6 \pm 2,61^{* *}$ \\
\hline Adaptive potential of the cardiovascular system, cond. units & $20,73 \pm 1,57$ & $70,58 \pm 2,35^{* * *}$ \\
\hline Systole blood volume, ml & $4,37 \pm 1,45$ & $4,89 \pm 2,41$ \\
\hline Minute blood volume, L/min & $0 \pm 1,41$ & $4,89 \pm 2,41$ \\
\hline Cardiac index, L/min/m ${ }^{2}$ & $-3,11 \pm 1,39$ & $-14,33 \pm 1,05^{* * *}$ \\
\hline General peripheral resistance, din ${ }^{2} \times$ sec/sm ${ }^{5}$ & $-7,59 \pm 1,36$ & $-8,44 \pm 1,36$ \\
\hline Cardio-vascular system functional state level, points & $8,75 \pm 1,48$ & $14,18 \pm 1,28^{* *}$ \\
\hline Vital lung capacity, ml & $2,18 \pm 1,36$ & $7,77 \pm 1,31^{* *}$ \\
\hline Inhalation breathing delay time, sec. & $5,01 \pm 1,35$ & $8,72 \pm 1,24 *$ \\
\hline Exhalation breathing delay time, sec. & $9,79 \pm 1,55$ & $20,74 \pm 1,24 * * *$ \\
\hline Hypoxia index, cond. units & $13,54 \pm 1,71$ & $28,26 \pm 1,22^{* * *}$ \\
\hline Skibinsky index, cond. units & $10,68 \pm 1,45$ & $24,85 \pm 1,33^{* * *}$ \\
\hline External breathing system functional state level, points & $2,91 \pm 1,45$ & $21,2 \pm 1,57^{* * *}$ \\
\hline
\end{tabular}

Note: $*-p<0,05 ; * *-p<0.01 ; * * *-p<0,001$ in comparison with the control group. 
The results of the comparative analysis of the values of the relative changes in the indicators of the cardiorespiratory system of the players of the control and experimental groups before the end of the study were quite indicative (Table 5).

They were characterized by significantly higher, compared with the control group, the rate of reduction of the degree of functional stress of the regulatory mechanisms of the cardiovascular system ( 3 times), increasing its adaptive capacity (3,5 times), all indicators of the external breathing system (2-3 times) ), as well as the cardio-vascular system functional state level ( 2 times) and the External breathing system functional state level (10 times).

\section{Conclusions}

Based on the analysis of the problem of optimizing the functional state of the cardiorespiratory system of football players at the stage of specialized basic training, the need for further improvement of training programs in the preparatory period of the annual macrocycle is shown due to lack of significant positive changes in cardiovascular system and external breathing system of young football players the influence of the traditional program of training sessions, which coincides with the data of researches of other authors.

It should be noted that for the first time, integrated indicators of the levels of the functional state of the cardiovascular system and the external breathing system were used to determine and assess the current level of the functional state of the cardiorespiratory system of football players. These indicators are one of the integral criteria for assessing and forecasting the level of functional preparedness of athletes and the effectiveness of the training process.

The presented results testified to the pronounced optimization of the level of functional preparedness of the experimental group players at the end of the preparatory period of the annual macrocycle and confirmed the high efficiency of our proposed program to build the training process of football players 15-17 year at the stage of specialized basic training.

Prospects for further research in this area are to further study the dynamics of the functional state of the cardiorespiratory system of young football players under the influence of new programs training process.

Sources of funding. This article has not received financial support from a government, community, or commercial organization.

\section{References}

Dyachenko A. (2000). Osoblivosti suchasnogo pidhodyou do oschinki funkzcionalnoy pidgotovlenosti sportsmeniv. Teoriya I metodika phizichnogo vihovannya i sportu. № 2-3. s. 46-50. Lisenchuk, H., Tyshchenko, V. (2019). Kompleksna otsinka spetsial'noyi fizychnoyi $i$ tekhniko-taktychnoyi pidhotovlenosti yak zaporuka formuvannya osnovnoho skladu u futboli. Fizychna kul'tura, sport ta zdorov"ya natsiyi: zbirnyk naukovykh prats'. Vyp. 8 (27), Zhytomyr: Vyd-vo ZHDU im. I. Franka, pp. 175-183.

Malikov, M.V., Bohdanovs'ka N.V., Svat'yev A.V. (2006). Funktsional'na diahnostyka v fizychnomu vykhovanni ta sporti. Zaporizhzhya: ZNU. $199 \mathrm{s.}$

Mizchenko V., Tomyak T., Dyachenko A. (2003). Individualnie osobennosti anaerobnih vozmoszhnostey kak komponenta specialnoy vinoslivosti sportsmenov. Nauka v olimpiyskon sporte. 2003. № 1. S. 57-62.

Nikolayenko, V.V., Avramenko, V.H., Honcharenko, V.I. (2003). Futbol: Navch. prohrama dlya dytyacho-yunats'kykh sportyvnykh shkil, spetsializovanykh dytyacho-yunats'kykh shkil 
olimpiys'koho rezervu ta shkil vyshchoyi sportyvnoyi maysternosti. Kyyiv: Nauk.-metod. komitet FFU, $106 \mathrm{~s}$.

Strykalenko, YE.A., Shalar, O.H., Huzar, V.M., Boychenko, A.V. (2020). Efektyvnist' eksperymental'noyi prohramy shvydkisno-sylovoyi pidhotovky futbolistiv 13-14 rokiv iz vykorystannyam blokiv spetsial'no pidibranykh vprav. Sportyvni ihry. Kharkiv: KHDAFK, 2020, № 3(17), 91-102.

Barba, F., Iturriaga, F.-M., Borges-Fernandes, P.-J. (2020). Effect of training in SSG on the ability to repeat sprints in young football players. Physical education and sport. Art 242. P. 1783.1790 .

Bujalance-Moreno, P., Latorre-Román, P.Á., García-Pinillos, F.A (2019). A systematic review on small-sided games in football players: Acute and chronic adaptations. Journal of sports sciences. T. 37. №. 8. P. 921-949.

Malikov, N., Konoh, A., Korobeynikov, G.,.Dudnyk, O., Ivaschenko, E. (2020). Physical condition improvement in elite volleyball players. Journal of Physical Education and Spore. Vol. 20(5). PP. 2686-2694.

Malikov, N., Tyshchenko, V., Bogdanovskya, N., Savchenko, V., Moskalenko, N., Ivanenko, S., Vaniuk, D., Orlov, A., Popov, S. (2021). Functional fitness assessment of elite athletes. Journal of Physical Education and Sport. Vol. 21 (1). PP. 374-380.

Menegassi, V., Rechenchosky, L., Borges, P., Nazario, P., Carneiro, A., Fiorese, L., Rinaldi, W. (2018). Impact of motivation on anxiety and tactical knowledge of young soccer players. Journal of Physical Education and Sport. № 18 (1). P. 170-174.

Turna, B., Alp, M. (2020). The Effects of Functional Training on Some Biomotor Abilities and Physiological Characteristics in Elite Soccer Players. Journal of Education and Learning. T. 9. № 1. P. 164-171. 